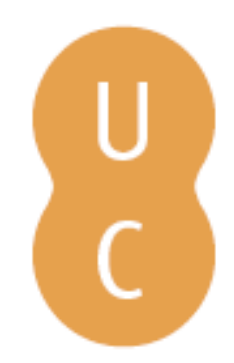

\title{
pommalina
}

\section{Detecting peatland combustion using shortwave and thermal infrared landsat-8 data}

Autor(es): $\quad$ Sofan, Parwati; Bruce, David; Jones, Eriita; Marsden, Jackie

Publicado por: Imprensa da Universidade de Coimbra

URL

persistente: URI:http://hdl.handle.net/10316.2/44623

DOI: $\quad$ DOI:https://doi.org/10.14195/978-989-26-16-506_106

Accessed : $\quad$ 26-Apr-2023 14:04:48

A navegação consulta e descarregamento dos títulos inseridos nas Bibliotecas Digitais UC Digitalis, UC Pombalina e UC Impactum, pressupõem a aceitação plena e sem reservas dos Termos e Condições de Uso destas Bibliotecas Digitais, disponíveis em https://digitalis.uc.pt/pt-pt/termos.

Conforme exposto nos referidos Termos e Condições de Uso, o descarregamento de títulos de acesso restrito requer uma licença válida de autorização devendo o utilizador aceder ao(s) documento(s) a partir de um endereço de IP da instituição detentora da supramencionada licença.

Ao utilizador é apenas permitido o descarregamento para uso pessoal, pelo que o emprego do(s) título(s) descarregado(s) para outro fim, designadamente comercial, carece de autorização do respetivo autor ou editor da obra.

Na medida em que todas as obras da UC Digitalis se encontram protegidas pelo Código do Direito de Autor e Direitos Conexos e demais legislação aplicável, toda a cópia, parcial ou total, deste documento, nos casos em que é legalmente admitida, deverá conter ou fazer-se acompanhar por este aviso. 


\section{ADVANCES IN}

\section{FOREST FIRE RESEARCH}

\section{8}

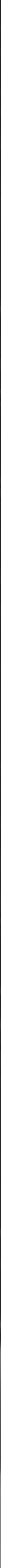




\title{
Detecting Peatland Combustion using Shortwave and Thermal Infrared Landsat-8 data
}

\author{
Parwati Sofan $^{1 *}$; David Bruce ${ }^{2}$; Eriita Jones ${ }^{3}$, Jackie Marsden ${ }^{4}$ \\ ${ }^{1}$ PhD candidate, the University of South Australia (UniSA); Remote Sensing Application Center of \\ Indonesian Institute of Aeronautics and Space (LAPAN), Adelaide South Australia, \\ \{parwati.sofan@mymail.unisa.edu.au*\} \\ ${ }^{2}$ Natural and Built Environments Research Centre, UniSA, Adelaide, South Australia, \\ \{david.bruce@unisa.edu.au\} \\ ${ }^{3}$ School of IT and Mathematical Sciences, UniSA. Adelaide, South Australia, \\ \{eriita.jones@unisa.edu.au\} \\ ${ }^{4}$ Imagery, Landgate. Midland, West Australia, \{Jackie.Marsden@landgate.wa.gov.au\}
}

\begin{abstract}
Peatland fires occur every year in Indonesia. These fires usually occur in the dry season due to agricultural and plantation expansion practices, which include slash and burn activities. Peatland combustion fires can be classified into smouldering and flaming. Smouldering is described by lower temperatures, spread rates and combustion power compared with flaming. Most of the standard fire products from remote sensing satellites use an apparent fire temperature at $4 \mu \mathrm{m}$ in the Middle Infrared (MIR) and background temperature at $11 \mu \mathrm{m}$ in Thermal Infrared (TIR). These products only report combustion in a single term as an "active fire" or "fire hotspot", and do not discriminate between smouldering and flaming states. In this research, the Shortwave Infrared (SWIR) and TIR bands of day-time Landsat-8 were explored to discriminate smouldering and flaming states of peatland combustion. Initial identification of possible combustion areas was from visual observation of false colour composite images (bands 764 to RGB) of Landsat-8, which presented smoke plumes in pale bluish tones emanating from a defined ground location. The potential combustion areas were further investigated using an implementation of the Hyperspectral Fire Detection Index based on SWIR of Landsat-8 and named here as the Shortwave Infrared Combustion Index (SICI). Potential combustion areas were also analysed using radiances of the SWIR (band 7) and TIR (band 10), which exhibited values close to their saturation. From these radiances, a radiative transfer model using MODTRAN4 and Planck's law, the fire temperatures were estimated. Preliminary results showed that the flaming states, with higher temperatures than smouldering states, are coincident with SWIR radiances near saturation $\left(24-29 \mathrm{Wm}^{-2} \mathrm{sr}^{-1} \mu \mathrm{m}^{-1}\right.$ for band 7) and TIR (band 10) $>12 \mathrm{Wm}^{-2} \mathrm{sr}^{-1} \mu \mathrm{m}^{-1}$, while smouldering states, with lower temperatures, occur near flaming areas with lower SWIR radiance and TIR radiance above $11 \mathrm{Wm}^{-2} \mathrm{sr}^{-1} \mu \mathrm{m}^{-1}$. Based on Landsat-8 imagery on $3^{\text {rd }}$ and $19^{\text {th }}$ August 2015, fire temperatures of flaming areas were estimated at $700-758 \mathrm{~K}$, mixtures of flaming and smouldering at $500-665 \mathrm{~K}$, and smouldering at $320-499 \mathrm{~K}$. This result aligned with prior research that sampled in situ smouldering, smouldering close to flaming, and flaming temperatures taken from Indonesian peatland. The algorithm developed in the research reported here was able to map some combustion areas that could not be mapped using lower spatial resolution imagery from MODIS. However, the results will undergo further investigation for atmospheric influence such as haze and thin cloud. Results also will be validated with other data such as field measurements. The algorithm developed in this research has potential to be used on a routine basis due to the availability of day-time Landsat- 8 data which, at best, has a temporal resolution of 16 days. It can also be implemented for forest fire detection at a detailed scale to complement other fire information, but again temporal resolution is an issue. This research is part of a larger project which is utilising automated smoke detection and soil moisture measurement in the mapping of peatland combustion from space imagery.
\end{abstract}

Keywords: Flaming, smouldering, peatland fires, Landsat-8, remote sensing, SWIR, TIR

Advances in Forest Fire Research 2018 - Page 969 


\section{Introduction}

In Indonesia, peatland combustion usually has an anthropogenic origin due to agricultural and plantation expansions, which are mostly accomplished through slash and burn activities (Miettinen et al. 2012; Rieley and Page 2016). Most peatland fires occur during the dry season (July-September) when the peatland is drier than in other times of the year and more susceptible to combustion (Usup et al. 2014, Hayasaka et al. 2016). The devastating forest and peatland fires in Indonesia in 2015 caused a total economic loss of about USD 16 billion (Worldbank 2016), released approximately $1.75 \mathrm{gt}$ of atmospheric CO2 (Worldbank 2016) and contributed to 100,000 premature deaths (Burrows 2016).

In general, peatland combustion consists of flaming and smouldering. Smouldering occurs with lower temperatures, spread rates and combustion power compared with flaming. Once ignition has occurred, smouldering can exist for long periods and extinguishment is dependent on heavy rainfall or fire-fighting attempts (Rein 2016; Zaccone et al. 2014). Determination of flaming and smouldering phases of peatland combustion from remote sensing data is important for peat fire management before the fire extends into a large area. However, routine satellite-based monitoring to supply smouldering and flaming information has not yet been effectively established. MODIS and VIIRS sensors, generate routine global active fire monitoring products with a low spatial resolution of $1000 \mathrm{~m}$ (MODIS), 375 $\mathrm{m}$ and $750 \mathrm{~m}$ (VIIRS). These sensors utilise the Middle Infrared (MIR) and Thermal Infrared (TIR) to detect active fires with algorithms utilising at a contextual approach, aimed at identifying a combustion pixel relative to a local background and consist of pathways to establish potential fire pixels (Justice et al. 2002; Giglio et al. 2016; Schroeder et al. 2014; Csiszar et al. 2014).

Research on detection of peatland combustion has been conducted with medium spatial resolution at 30-100 m, Landsat-8 night-time data, using an implementation of Planck's Law on radiant emission and temperature from Shortwave Infrared (SWIR) and TIR in Indonesia's Kalimantan peatland (Elvidge et al. 2015). At night, no sunlight interferes with the SWIR and TIR radiances over fire areas with sensors only recording emitted radiation. However, the availability of Landsat- 8 night-time data is limited with provision only for special requests. There is a possibility to utilise day-time Landsat- 8 data, which is freely available every 16 days (atmosphere permitting) to produce flaming and smouldering information. Flaming detection has been explored by Schroeder et al. (2016) who measured SWIR radiance (band 7) of Landsat-8, which reached saturation from $30 \mathrm{~m} 2$ areas of woody burning material in Germany and Brazil, where ground fire temperatures were measured between 870 and $970 \mathrm{~K}$ as obtained from a thermal handheld sensor. Dennison and Roberts (2009) found that SWIR bands at 2.061 and $2.429 \mu \mathrm{m}$ could be utilised in the Hyperspectral Fire Detection Index (HFDI) for flaming detection. Meanwhile, the detection of peatland smouldering based on satellite remote sensing in day-time data remains a challenge, due to its lower radiant emission than that from flaming. The lower temperature of smouldering combustion may be more accurately captured through the use of the longer wavelength infrared or TIR.

In this research, investigation of day-time Landsat- 8 data was conducted to distinguish peatland flaming and smouldering states. Landsat- 8 has the spectral capability to detect combustion from SWIR and TIR, and also with its medium spatial resolution of $30 \mathrm{~m}$ and $100 \mathrm{~m}$, potentially able to detect small burning areas that are often found in the field especially in the initial stages of combustion. This information will be useful for early fire suppression before it extends into a larger area.

\section{Materials and Methods}

The study area for this research is located in Central Kalimantan, one of the severe peat fire areas in Indonesia. Level 1T (Terrain Corrected) Landsat 8 data (path/row 118/062; August 3rd and 19th, 2015) of the study area were accessed through the U.S. Geological Survey (USGS) Earth Explorer website. The MODIS fire-mask product-collection 6 for both days 3rd and 19th August 2015 were used in order to compare with the Landsat-8's results. 
The first identification of possible combustion was from visual inspection of the false colour image composite: bands 764 to Red Green Blue (RGB). Potential combustion areas were further investigated using a SWIR index which is here named as the Shortwave Infrared Combustion Index (SICI), the ratio of radiance of bands 6 and 7 of Landsat-8, combined with the SWIR and TIR radiances. Based on Planck's Law (relating temperature and wavelength), smouldering fire states will have lower SWIR radiance than flaming, and higher TIR radiance. Subsequently the combustion temperature was estimated using a radiative transfer model (MODTRAN4) combined with Planck's equation for SWIR and TIR (Barduci et al. 2004; Qian and Kong 2012). To evaluate the precision of the combustion detection, the results were overlaid with the same data of RGB images of Landsat-8. In addition, the results were also compared with the MODIS fire-mask product.

\section{Results and Discussion}

\subsection{Peat Combustion Identification}

Since the ground validation of peatland combustion was not available at the date of Landsat- 8 observations of the study area, the potential combustion areas were visually interpreted from the RGB764 of Landsat-8. There were 9 and 22 samples of potential combustion areas visible in these images in August 3rd and 19th, 2015 respectively in Central Kalimantan's peatland, as shown in Figure 1a and $1 \mathrm{~b}$. The enlarged picture of sample number 9 in Figure 1a shows bluish smoke emanating from combustion areas surrounding the burnt area in magenta tones. Sixteen days after that, Figure $1 \mathrm{~b}$ showed an extended burnt area in and around and south-west of sample number 9 with some active combustion areas showing bluish smoke in the lower-left part of burnt area. The combustion pixels exhibit in light yellow tones surrounded with orange and pink tones. All the potential combustion areas and non-combustion areas were then analysed statistically to obtain the radiance value of each SWIR and TIR band of Landsat-8. The potential combustion areas and non-combustion areas were chosen by selecting the area which has SWIR and TIR radiances less than and equal to $33 \%$ of coefficient of variation (the ratio of the standard deviation to the mean) from each landcover. In the study area, the landcover types which represented the non-combustion areas were burnt area, forest, and urban. Most combustion areas were located around burnt areas or vegetated areas (forest) as extensions of plantation areas. Urban/city areas are typically bright (high radiance) and therefore could be a potential source of commission errors in the calculation of combustion area. The selected areas are shown in Figure 1a. There were 563 potential combustion pixels. Non-combustion areas consisted of 1,594 pixels of burnt area, 84,049 pixels of forest, and 8,424 pixels of urban that were visually interpreted from the RGB images of Landsat-8. In Figure 1c box plots contain the minimum, quartile-1, median, quartile-3, and maximum values for combustion and non-combustion areas for every SWIR's radiance (band 6 and 7) and TIR's radiance (band 10). These show, not unsurprisingly, that combustion areas had highest radiance in bands 6 and 7 compared with other objects, while in band 10 the radiances of combustion areas were close to those of burnt areas. Some of the pixels in the combustion areas were close to saturation at radiances of $89.8,28.5$, and $20.9 \mathrm{Wm}-2 \mathrm{sr}-1 \mu \mathrm{m}-1$ at band 6 , band 7 , and band 10 , respectively. Even though the median values of combustion and burnt areas were about $11 \mathrm{Wm}-2 \mathrm{sr}-$ $1 \mu \mathrm{m}-1$, none of the burnt area radiances were close to saturation in band 10. In Figure 1d, the SICI box plot of combustion areas shows about $75 \%$ of SICI were different to burnt area SICI values. About $25 \%$ of the SICI values in combustion areas exhibited the same values as that of burnt and urban areas. In order to have the maximum identification of potential combustion areas, and minimum mixture with burnt and urban areas, SICI values less than the 1st quartile of burnt areas (3.0) were adopted. The SICI value at 3.0 is shown with a blue line in Figure 1d. The potential combustion areas were then investigated further using radiance values of bands 7 and 10 as presented in Figure 1c to separate the combustion areas from non-combustion areas (burnt area, urban, and forest). 
a)
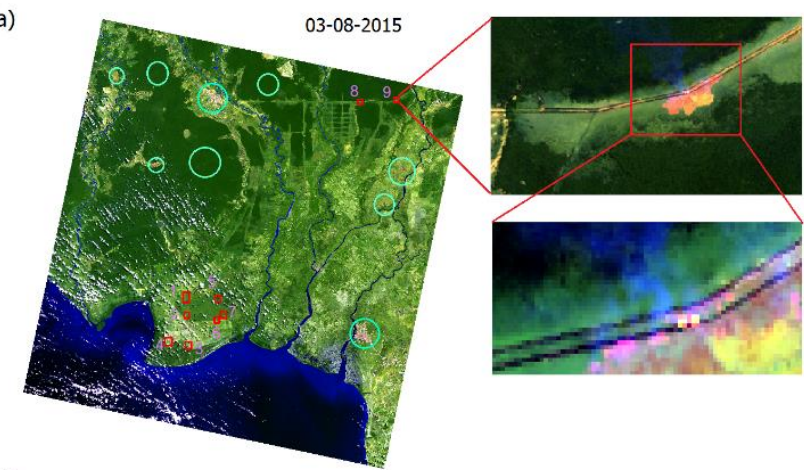

b)

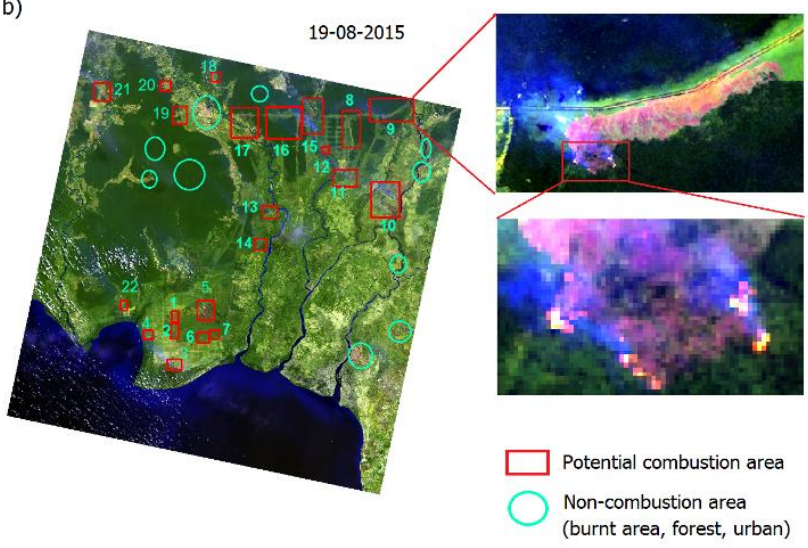

c)
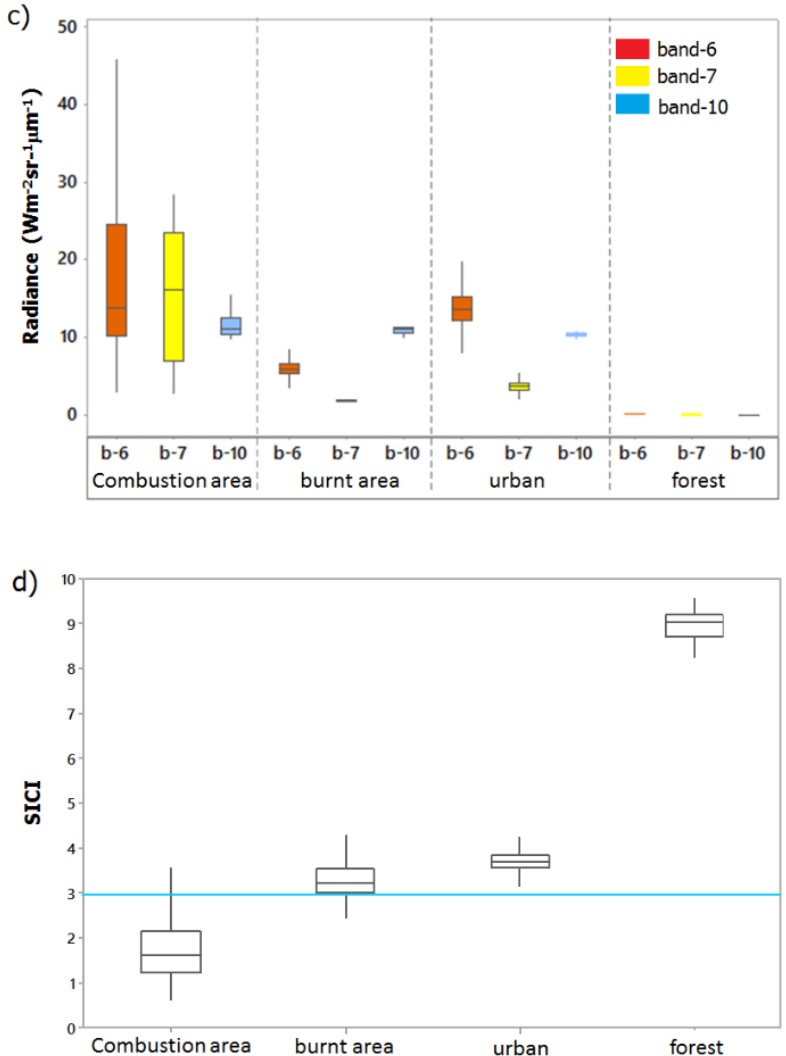

Figure 1 - $(a, b)$ The 764-RGB image of Landsat-8 on August $3^{\text {rd }}$ and August 19 ${ }^{\text {th }}$, 2015 with 9 samples and 21 samples respectively of potential combustion areas shown inside red squares and non-combustion areas inside cyan circles, respectively. An enlargement of one potential combustion sample area is presented on the right side of each Landsat image, (c) Box plots of radiance values of SWIR and TIR bands over combustion, burnt, forest, and urban areas, (d) SICI's box plots in combustion and non-combustion areas with the blue line indicating a threshold of 3.0 (the $1^{\text {rd }}$ quartile value of burnt area) which was used to separate combustion from other areas. 
An example of identification of peatland combustion using the SICI, SWIR radiance, and TIR radiance is shown in Figure 2. The combustion area in the 764-RGB image, shown in orange to yellow tones (Fig. 2a), had radiance values that were close to SWIR (band 7) saturation at $24-29 \mathrm{Wm}-2 \mathrm{sr}-$ $1 \mu \mathrm{m}-1$ (Fig. 2b). This agreed with findings by Schroeder et al. (2016). These areas are observed with TIR radiance greater than $12 \mathrm{Wm}-2 \mathrm{sr}-1 \mu \mathrm{m}-1$ (saturation occurs at $20.9 \mathrm{Wm}-2 \mathrm{sr}-1 \mu \mathrm{m}-1$ for band 10) (Fig. 2c). SICI values less than 3 represented the potential combustion area shown in Fig. 2d. Pixels with SWIR and TIR's radiance close to saturation were assumed in a flaming stage (Fig. 2e), while the other neighbouring pixels located inside the SICI $<3$ area with lower radiance values than flaming pixel, i.e. $11-20 \mathrm{Wm}-2 \mathrm{sr}-1 \mu \mathrm{m}-1$ for band 7 and $11-20.9 \mathrm{Wm}-2 \mathrm{sr}-1 \mu \mathrm{m}-1$ for band 10 , were assumed to be in a smouldering stage (Fig. 2f); these corresponded to the orange tones in the 764-RGB image (Fig 2a). The classified flaming and smouldering areas were merged in Fig. 2g. However, some of combustion pixels were not identified as flaming or smouldering pixels in Fig. $2 \mathrm{~g}$. These were then classified as mixed pixels, exhibiting both flaming and smouldering states. The mixed pixels had lower TIR (band 10) radiances compared with flaming and smouldering pixels. In Figure $2 \mathrm{~h}$, the mixed flaming and smouldering pixels are mapped in a cyan tone. The median values of SICI of flaming, smouldering, and mixture of flaming and smouldering pixels were 1.4, 2.2, and 2.6, respectively (Fig. 2i).
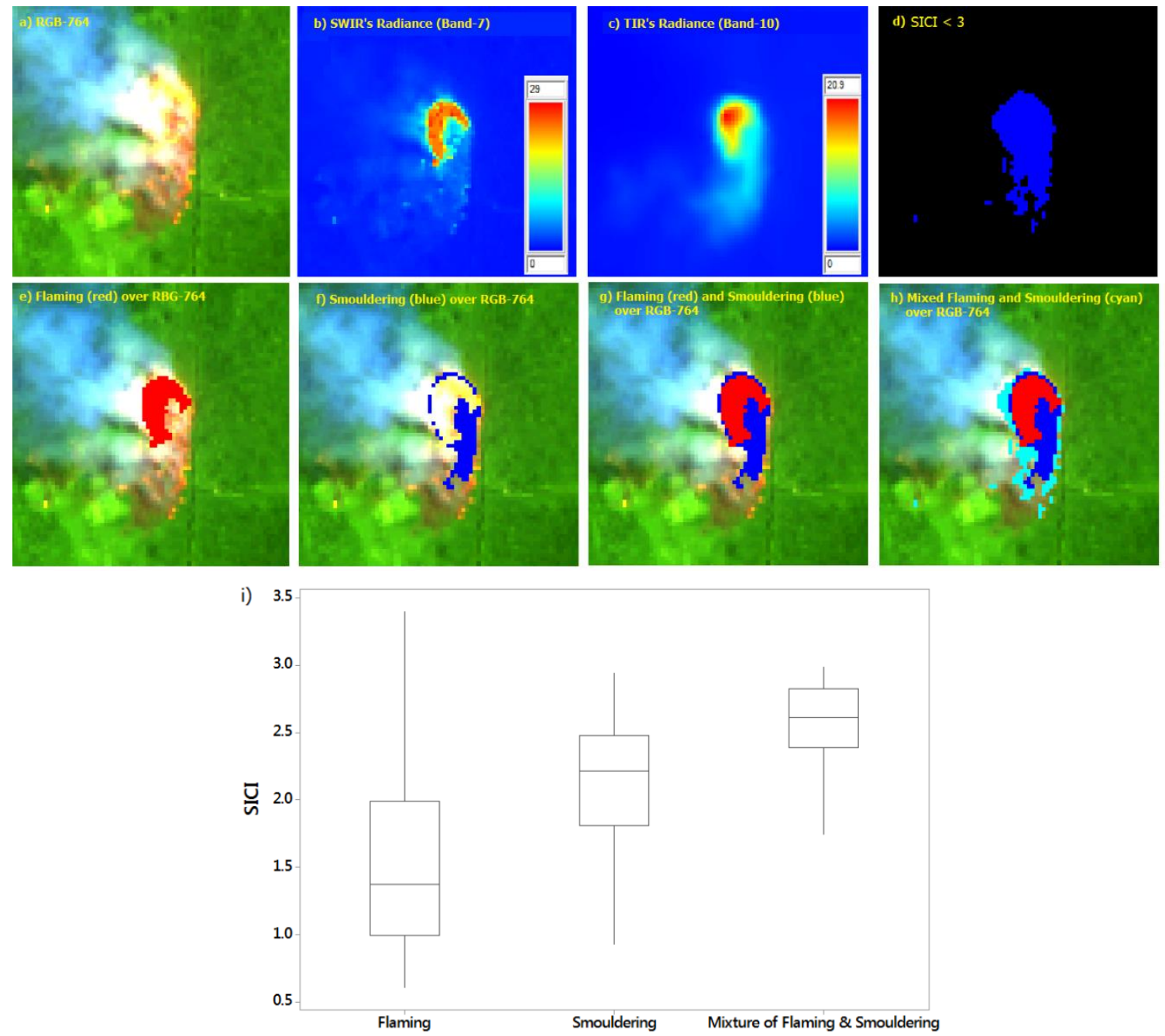

Figure 2 -Example of peatland combustion identification (a) Smoke in pale bluish tones showed in 764-RGB with the potential combustion area in orange to yellow tones, $(b \& c)$ Pseudo colour of the radiance of band-7 and band-10 respectively were just under / at saturation, (d) The SICI <3 in blue as the potential combustion area, $(e, f, g)$ The identified flaming (red) and smouldering (blue) areas, (h) Mixture of flaming and smouldering areas shown in cyan over the 764-RGB image, (i) Box plots of SICI over flaming, smouldering, and mixture of flaming and smouldering areas 


\subsection{Fire Temperature Estimation}

The estimated fire temperature based on SWIR (bands 6-7) and TIR (band 10) over identified combustion pixels in Landsat-8 images on $3^{\text {rd }}$ and $19^{\text {th }}$ August 2015 is plotted in Figure 3. Figure 3a shows a boxplot representing the minimum, quartile $1^{\text {st }}$, median, quartile $3^{\text {rd }}$ and maximum values of smouldering (S), mixture of flaming and smouldering (FS), and flaming (F). There were $402 \mathrm{~S}$ pixels in range of $320 \mathrm{~K}$ to $499 \mathrm{~K}, 8,587 \mathrm{FS}$ pixels in range of $500 \mathrm{~K}$ to $665 \mathrm{~K}$, and $103 \mathrm{~F}$ pixels with temperature of $700 \mathrm{~K}$ to $758 \mathrm{~K}$. The median values of S, FS, and F temperatures were about $476 \mathrm{~K}$, $585 \mathrm{~K}$, and $722 \mathrm{~K}$, respectively. According to Usup et al (2014), smouldering temperatures observed from ground measurements were about 320 - $500 \mathrm{~K}$, and Elvidge et al (2015) found smouldering close to flaming at about $500-700 \mathrm{~K}$, and flaming at about $700-1000 \mathrm{~K}$. Thus, the estimated peatland fire temperatures from Landsat- 8 in all the peatland combustion stages were in the range of those provided by Usup et al (2014) and Elvidge et al (2015) but estimated flaming temperatures could not be higher than $758 \mathrm{~K}$ due to the saturation of band-6 in Landsat-8. Figure $3 \mathrm{~b}$ shows a dotplot of $\mathrm{S}$, FS, and F temperatures with each dot representing the average of up to 32 observations. The dotplot shows the distribution of the estimated fire temperature from SWIR and TIR bands. Figure $3 \mathrm{~b}$ also shows the distribution of FS temperature with two peaks of temperature of $505 \mathrm{~K}$ and $595 \mathrm{~K}$ which represented the most common temperatures in FS. However, the dotplot of FS shows a left skewed distribution which possibly means a higher contribution of flaming than smouldering temperatures.

a)

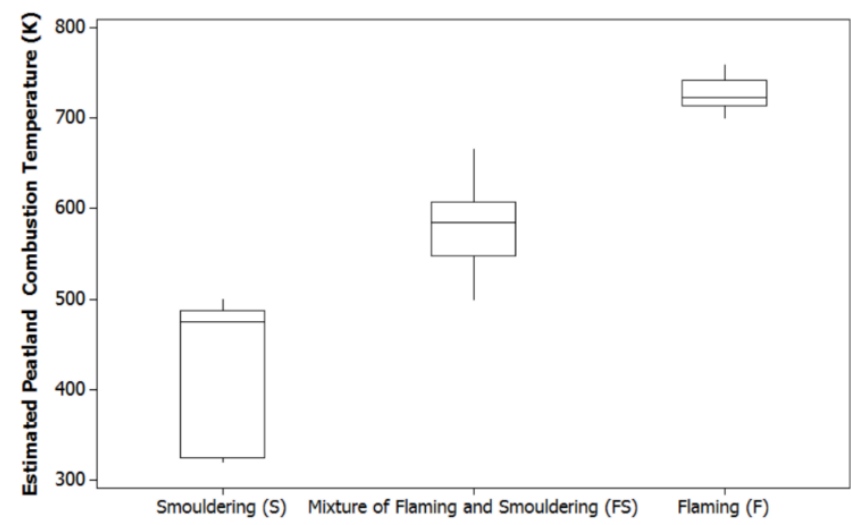

b)

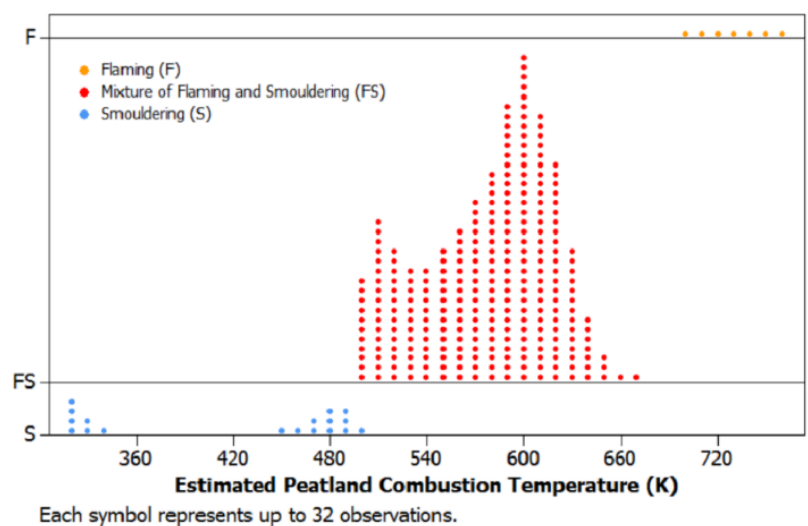

Figure 3 - (a) Boxplot represents the minimum, quartile $1^{\text {st }}$, median, quartile $3^{\text {rd }}$ and maximum values of smouldering

$(S)$, mixture of flaming and smouldering (FS), and flaming $(F),(b)$ The dotplot of estimated peatland combustion temperature on F, FS, and $S$ with two peaks of temperature and left-skewed distribution indicating a higher contribution of flaming than smouldering to FS temperature. 


\subsection{Precision and Comparison}

The methodology outlined in section 3.1 was implemented over 2 images including all 31 of potential combustion areas and non-combustion areas. Table 1 shows the 31 of potential combustion areas identified as flaming $(\mathrm{F})$, smouldering $(\mathrm{S})$ or mixture of flaming and smouldering $(\mathrm{FS})$. Overall, the result of combustion identification over all the 31 samples shows good mapping precision (Table 1). The mixture of flaming and smouldering pixels was identified in all the samples, while flaming or smouldering did not exist in every sample. The spatial resolution $(100 \mathrm{~m})$ of TIR may lead to the apparent mixture of flaming and smouldering stages. In one case, the mixture of flaming and smouldering was also found in a commission error in a burnt area separate from a combustion area. In one combustion area experiencing smoky conditions, the flaming and smouldering detection had an omission error leading to less combustion pixels being detected. The mixed flaming and smouldering pixels were also over mapped, producing commission errors over urban areas. The total hit detection was 31 samples with 1 sample of omission error and 6 samples of commission error. Overall, the precision of combustion detection was about $77 \%$ compared to the visual interpretation of 764-RGB image. This is an early estimation of mapping precision and is not an estimate of accuracy which can only be achieved with independent data such as ground data. To reduce omission and commission errors issues associated with smoke, cloud, urban land cover, and bright objects will be dealt with in the next step in the research.

Table 1 - Detection of flaming (F), smouldering (S), and mixture of flaming and smouldering (FS) over 2 Landsat-8 images (03-082015 and 19-08-2015). The hit, Commission $(C)$ and Omission $(O)$ Errors were derived from comparison with the 764-RGB of Landsat-8.

\begin{tabular}{|c|c|c|c|c|c|c|c|c|c|c|c|c|c|}
\hline \multicolumn{7}{|c|}{ Landsat-8 (03-08-2015) } & \multicolumn{7}{|c|}{ Landsat-8 (19-08-2015) } \\
\hline \multirow{2}{*}{ No } & \multicolumn{3}{|c|}{ Hit } & \multirow{2}{*}{0} & \multirow{2}{*}{$\mathrm{C}$} & \multirow{2}{*}{ Note } & \multirow{2}{*}{ No } & \multicolumn{3}{|c|}{ Hit } & \multirow{2}{*}{$\mathbf{O}$} & \multirow{2}{*}{$\mathbf{C}$} & \multirow{2}{*}{ Note } \\
\hline & $\mathbf{F}$ & $\mathbf{S}$ & FS & & & & & $\mathbf{F}$ & $\mathbf{S}$ & FS & & & \\
\hline 1 & $\checkmark$ & - & $\checkmark$ & - & - & with smoke & 1 & $\begin{array}{lll} & \\
\end{array}$ & - & $\checkmark$ & - & - & with smoke \\
\hline 2 & $\checkmark$ & - & $\checkmark$ & - & - & with smoke & 2 & $\checkmark$ & & $\checkmark$ & - & - & $\begin{array}{l}\text { with smoke; Extended burning area from 03- } \\
08-2018\end{array}$ \\
\hline 3 & $\checkmark$ & - & $\checkmark$ & - & $\checkmark$ & $\begin{array}{l}\text { Commission on FS } \\
\text { over burnt area }\end{array}$ & 3 & $\checkmark$ & $\checkmark$ & $\checkmark$ & - & - & with smoke \\
\hline 4 & - & - & $\checkmark$ & - & $\checkmark$ & No smoke & 4 & $\checkmark$ & - & $\checkmark$ & - & $\checkmark$ & No smoke \\
\hline 5 & $\checkmark$ & - & $\checkmark$ & - & - & with smoke & 5 & $\checkmark$ & - & $\checkmark$ & - & - & $\begin{array}{l}\text { Extended burning area from 03-08-2018 with } \\
\text { smoke }\end{array}$ \\
\hline 6 & $\checkmark$ & - & $\checkmark$ & - & - & with smoke & 6 & $\checkmark$ & $\checkmark$ & $\checkmark$ & - & - & $\begin{array}{l}\text { Extended burning area from 03-08-2018 with } \\
\text { smoke }\end{array}$ \\
\hline 7 & - & - & $\checkmark$ & - & - & No smoke & 7 & $\checkmark$ & - & $\checkmark$ & - & - & No smoke \\
\hline 8 & - & - & $\checkmark$ & - & - & with smoke & 8 & $\checkmark$ & - & $\checkmark$ & - & - & with smoke \\
\hline 9 & $\checkmark$ & - & $\checkmark$ & - & - & with smoke & 9 & $\checkmark$ & $\checkmark$ & $\checkmark$ & - & - & with smoke \\
\hline \multirow{14}{*}{$*$} & & & \multirow{14}{*}{ - } & \multirow{14}{*}{ - } & \multirow{13}{*}{$\checkmark$} & \multirow{14}{*}{$\begin{array}{l}\text { Non-combustion } \\
\text { area, commission } \\
\text { error of FS over } \\
\text { urban and cloud }\end{array}$} & 10 & $\checkmark$ & $\checkmark$ & $\checkmark$ & - & $\checkmark$ & $\begin{array}{l}\text { with smoke; commission of FS over burnt } \\
\text { area }\end{array}$ \\
\hline & & & & & & & 11 & $\checkmark$ & - & $\checkmark$ & - & - & with smoke \\
\hline & & & & & & & 12 & - & - & $\checkmark$ & - & - & with smoke \\
\hline & & & & & & & 13 & $\checkmark$ & $\checkmark$ & $\checkmark$ & $\checkmark$ & - & less detection over smoky condition \\
\hline & & & & & & & 14 & - & $\checkmark$ & $\checkmark$ & - & - & with smoke \\
\hline & & & & & & & 15 & $\checkmark$ & $\checkmark$ & $\checkmark$ & - & - & with smoke \\
\hline & - & - & & & & & 16 & $\checkmark$ & $\checkmark$ & $\checkmark$ & - & - & with smoke \\
\hline & & & & & & & 17 & $\checkmark$ & - & $\checkmark$ & - & - & with smoke \\
\hline & & & & & & & 18 & - & - & $\checkmark$ & - & - & with smoke \\
\hline & & & & & & & 19 & $\checkmark$ & $\checkmark$ & $\checkmark$ & - & - & with smoke \\
\hline & & & & & & & 20 & $\checkmark$ & - & $\checkmark$ & - & - & with smoke \\
\hline & & & & & & & 21 & - & $\checkmark$ & $\checkmark$ & - & - & with smoke \\
\hline & & & & & & & 22 & $\checkmark$ & & & - & - & with smoke \\
\hline & & & & & & & * & - & - & - & - & $\checkmark$ & $\begin{array}{l}\text { Non-combustion area, commission error of FS } \\
\text { over urban }\end{array}$ \\
\hline
\end{tabular}


In addition to precision analysis, the results were also compared with the MODIS fire-mask product at the same date and the same location, but slightly different in time. In the first image acquired on August $3^{\text {rd }}, 2015$, there was only one MODIS acquisition at the location with a time about 4 hours later than Landsat-8 (Landsat- 8 acquired at 09.34 am while MODIS at $01.35 \mathrm{pm}$ ). According to Usup et al. (2004) the maximum spreading time of peatland fire is $6.5 \mathrm{~cm} /$ hour at the peat surface $(0-20 \mathrm{~cm})$; thus within 4 hours of the Landsat- 8 observation the MODIS observations of the peatland fires potentially corresponded to combustion $26 \mathrm{~cm}$ different in position to that observed by Landsat 8 . However, of all nine samples of combustion areas found in Landsat-8, the MODIS fire-mask only detected one at location number 2 (Figure 4). The MODIS fire mask did not detect the other eight combustion areas. Of the eight combustion areas not detected by the MODIS fire-mask product, two combustion areas were cloud covered, which possibly caused the non-detection of fire, while six combustion areas with clear sky were undetected by MODIS.

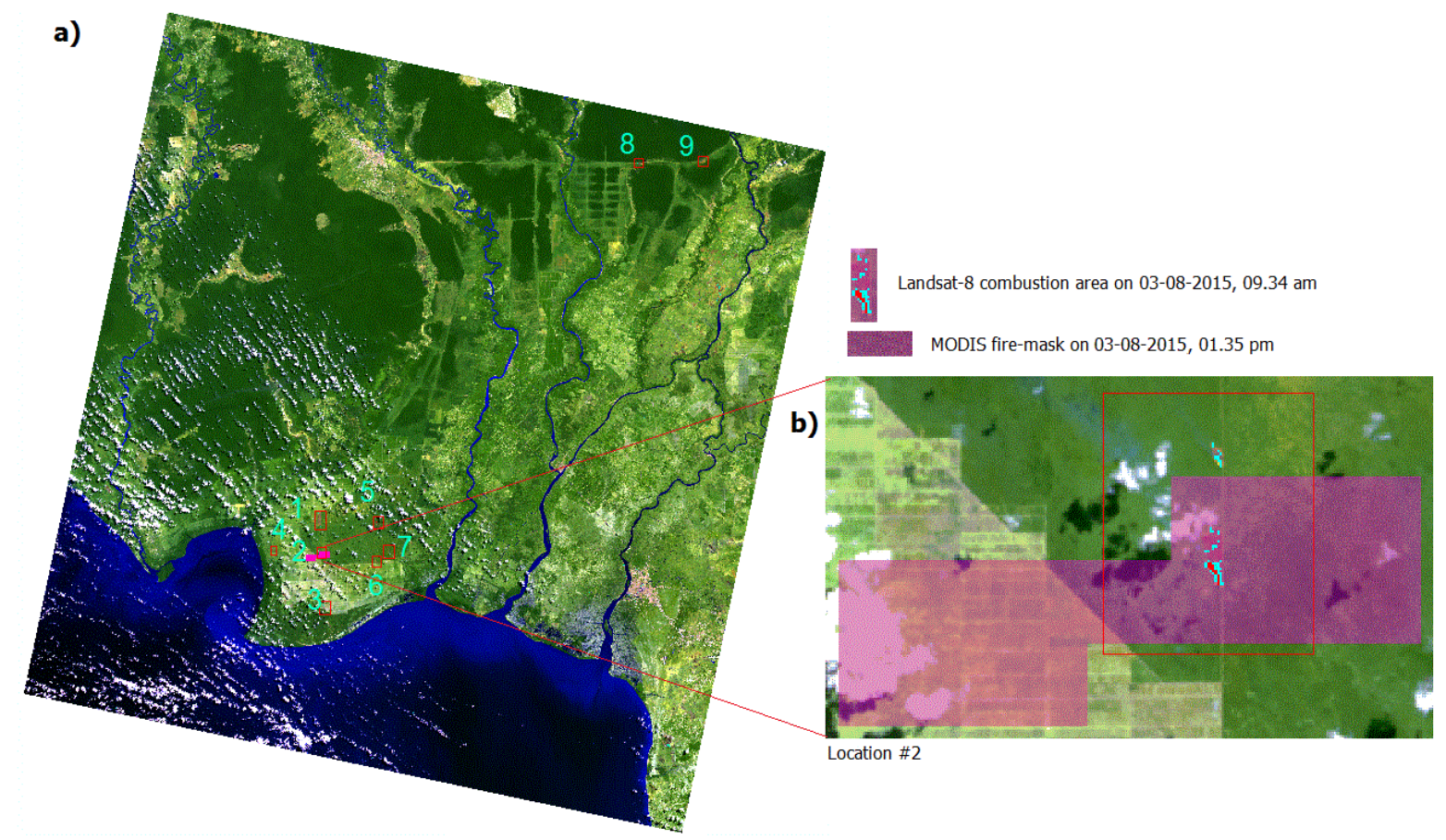

Figure 4 - (a) The 9 combustion areas shown in red square and MODIS fire-mask (pink) overlaid on the Landsat-8 764-RGB image of August $3^{\text {rd }}$, 2015. The MODIS fire-mask only appeared in location \#2, (b) Enlargement of location \#2 showing the MODIS fire-mask (pink) transparency overlaid on the Landsat-8 image which is showing a combustion area in red and cyan (centre right).

The second Landsat- 8 image in study area was acquired on $19^{\text {th }}$ August 2015 at 09.35 am, while on the same date and location MODIS fire-masks were available at $01.35 \mathrm{pm}$ and $10.20 \mathrm{pm}$, thus generating a difference in time with the Landsat acquisition of about 4 hours and 12 hours respectively. These time differences translate to maximum peat fire spread of about $26 \mathrm{~cm}$ and $78 \mathrm{~cm}$ (Usup et al 2004), respectively. Figure 5a shows the 22 combustion areas (red squares) on the 764-RGB image of Landsat- 8 overlaid with MODIS fire-mask data at $01.35 \mathrm{pm}$ (magenta) and $10.20 \mathrm{pm}$ (yellow). There were only six combustion areas detected by the MODIS fire-mask at $01.35 \mathrm{pm}$, with only two of them remaining detected at $10.20 \mathrm{pm}$, and two other combustion areas additionally detected at $10.20 \mathrm{pm}$; thus, a total of 8 combustion areas detected by MODIS fire-mask. Of the other 14 combustion areas not detected by MODIS fire-mask, five of them were due to cloud cover, while the nine remaining combustion areas were undetected even with a clear sky condition. Figure $5 b$ is the enlargement of combustion areas 15 and 16, which matched with the MODIS fire-mask, while in Figure 5c there was one commission error of MODIS fire-mask at 01.35 pm over a bare plantation area. 
Overall, the comparison of data from the MODIS fire-mask for peat combustion areas with combustion identified from Landsat- 8 resulted in 9 agreements (29\%) out of 31 for combustion, while 22 areas were undetected (71\%). The undetected combustion areas in the MODIS fire-mask were due to cloud cover ( 7 areas), low fire temperature and MODIS pixel size, which at $1 \mathrm{~km}$ would reduce detectability of small fires. One commission error in the MODIS fire mask was also found over a bare plantation area.

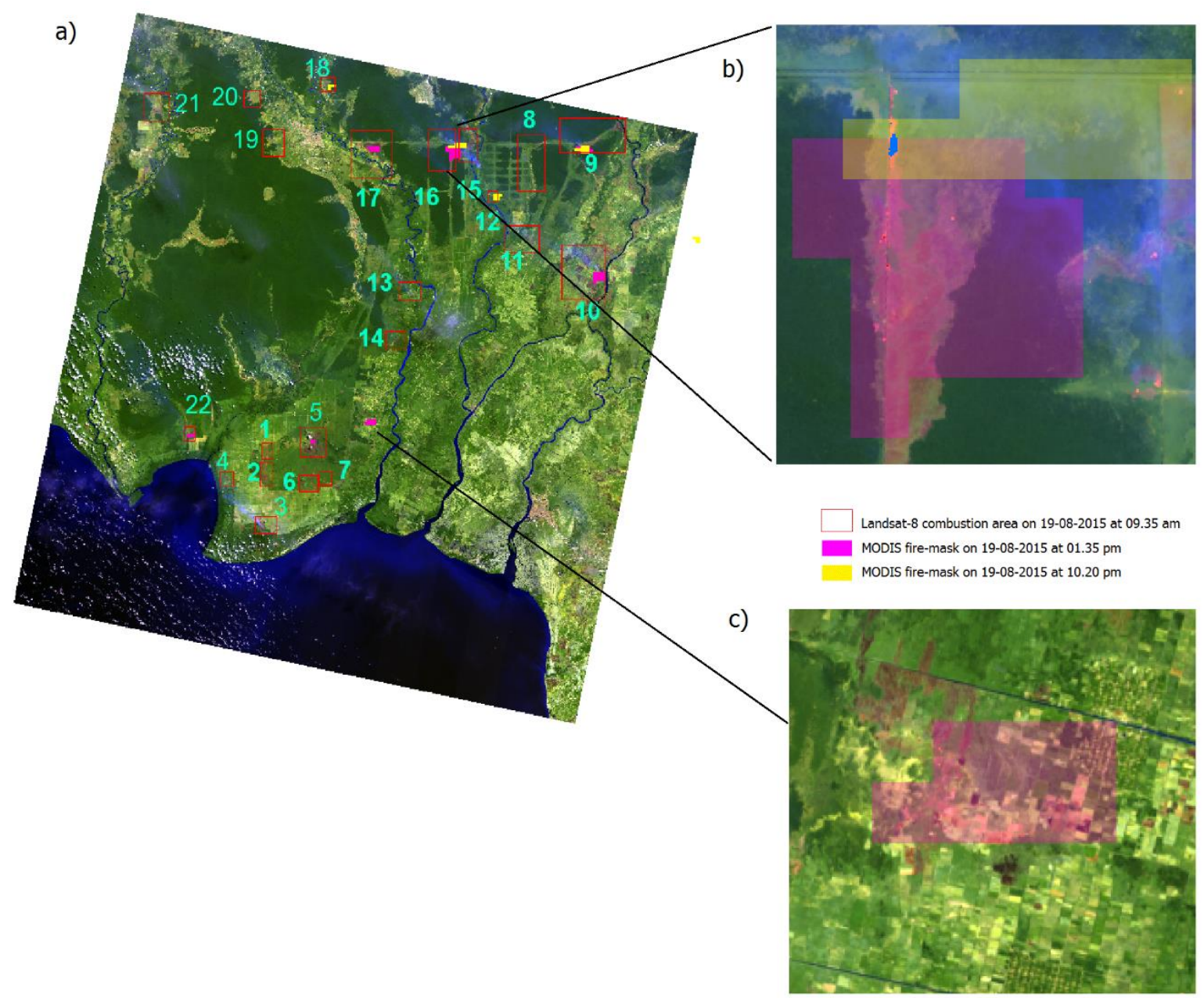

Figure 5 - a) The 22 combustion areas shown in red squares and MODIS fire-mask (pink and yellow) overlaid on the Landsat-8 764-RGB image of August 19 ${ }^{\text {th }}, 2015$, b) Enlargement of locations of \#15 and \#16 showing the MODIS fire-mask (pink and yellow) transparency overlaid on Landsat-8's combustion area; the blue polygon represents smouldering area generated from Landsat-8, c) Enlargement of commission error of MODIS fire-mask at 01.35 pm over bare plantation area.

\section{Conclusion}

Analysis of the SWIR and TIR bands of day-time Landsat-8 data indicates that it is potentially possible to discriminate flaming and smouldering stages in peatland combustion. The SICI integrated with the radiances of band- 7 and band- 10 of Landsat- 8 can be used for separating combustion and non-combustion areas. The detected peatland combustion showed about $77 \%$ precision compared with visual observations of the 764-RGB images of Landsat-8. Whilst there is room for further improvement, this is significantly better than the $71 \%$ of MODIS fire-mask which is widely used for global fire monitoring. The algorithm when applied to Landsat 8 imagery was able to detect combustion areas that could not be mapped using the lower spatial resolution MODIS fire-mask, especially in small burning areas as usually occur in peatland fires. The estimated peat fire 
temperatures from Landsat- 8 aligned with prior research, but the estimated flaming temperatures can not be higher than $758 \mathrm{~K}$ due to the saturation temperature of Landsat-8. However, further analysis is required for verification with a simultaneous field measurements. This algorithm has the potential to be used on a routine basis due to the availability of Landsat- 8 data during day-time every 16 days, provided cloud cover permits. It is possible that some merging of information from Landsat and higher temporal but lower spatial resolution satellites (e.g. Sentinel-2 and Sentinel-3, and maybe Himawari) can assist in interpolating the temporal gaps in Landsat data and when cloud cover inhibits use of Landsat. The algorithm presented in this research can also be implemented for forest fire mapping at a detailed scale, as its spatial resolution $(30 \mathrm{~m})$ is higher than the standard fire products $(1 \mathrm{~km})$. We are currently trialling and validating other algorithms with further research ongoing, as this work is part of a larger project, which is investigating automated smoke detection and soil moisture measurements in the mapping of peatland combustion.

\section{Acknowledgements}

This research was funded by the Research and Innovation in Science and Technology Project (RISET-Pro), Ministry of Research, Technology and Higher Education of the Republic of Indonesia (Kemenristekdikti) and the University of South Australia.

\section{References}

\%Barducci A, Guzzi D, Marcoionni P, Pippi, I (2004) Comparison of fire temperature retrieved from SWIR and TIR hyperspectral data. Infrared Physics \& Technology 46, 1-9. doi:10.1016/j.infrared.2004.03.001

Burrows L (2016) Smoke from 2015 Indonesian fires may have caused 100,000 premature deaths. Harvard John A. Paulson School of Engineering and Applied Sciences. updated 19 September 2016, viewed 10 February 2018, <https://www.seas.harvard.edu/news/2016/09/smoke-from-2015Indonesian-fires-may-have-caused-100000-premature-deaths>

Csiszar I, Schroeder W, Giglio L, Ellicott E, Vadrevu KP, Justice CO, Wind B (2014) Active fires from the Suomi NPP Visible Infrared Imaging Radiometer Suite: Product status and first evaluation results. Journal of Geophysical Research: Atmospheres 119, 803-816. doi:10.1002/

2013JD020453

Dennison PE, Roberts DA (2009) Daytime fire detection using airborne hyperspectral data. Remote Sensing of Environment 113, 1646-1657. doi: 10.1016/j.rse.2009.03.010

Elvidge CD, Zhizhin M, Hsu F, Baugh K, Khomarudin M, Vetrita Y, Sofan P, Suwarsono, Hilman D (2015) Long-wave infrared identification of smouldering peat fires in indonesia with nighttime landsat data. Environmental Research Letters 10, 065002. doi:10.1088/1748-9326/10/6/065002

Giglio L, Schroeder W, Justice C (2016) The collection 6 MODIS active fire detection algorithm and fire products. Remote Sensing of Environment 178, 31-41. doi:10.1016/j.rse.2016.02.054

Hayasaka H, Takahashi H, Limin SH, Yulianti N, Usup A (2016) Peat Fire Occurrence. In 'Tropical Peatland Ecosystems'. (Eds M Osaki, N Tsuji) pp. 377-395. (Springer: Tokyo). doi: 10.1007/9784-431-55681-7_25

Justice C, Giglio L, Korontzi S, Owens J, Morisette J, Roy D, Descloitres J, Alleaume S, Petitcolin F, Kaufman Y (2002) The MODIS fire products. Remote Sensing of Environment 83, 244-262.

Miettinen J, Hooijer A, Wang J, Shi C, Liew SC (2012) Peatland degradation and conversion sequences and interrelations in Sumatra. Regional Environmental Change. 12, 729-737. doi: $10.1007 / \mathrm{s} 10113-012-0290-9$ 
Qian, YG, Kong XS (2012) A method to retrieve subpixel fire temperature and fire area using MODIS data. International Journal of Remote Sensing 33, 5009-5025. doi: 10.1080/01431161.2012.657365

Rein G (2016) Smouldering Combustion. In 'SFPE Handbook of Fire Protection Engineering'. (Eds MJ Hurley) pp. 581-603. (Springer: New York). doi: 10.1007/978-1-4939-2565-0_19

Rieley J, Page S (2016) Tropical Peatland of the World. In 'Tropical Peatland Ecosystems'. (Eds M Osaki, N Tsuji) pp. 3-32. (Springer, Tokyo). doi: 10.1007/978-4-431-55681-7_1

Schroeder W, Oliva P, Giglio L, Csiszar I (2014) The New VIIRS 375 m active fire detection data product: Algorithm description and initial assessment. Remote Sensing of Environment 143, 85-96. doi: 10.1016/j.rse.2013.12.008

Usup A, Hashimoto Y, Takashi H, Hayasaka H (2004) Combustion and thermal characteristics of peat fire in tropical peatland in Central Kalimantan, Indonesia. Tropics 14, 1-19.

World Bank (2016) The Cost of Fire: An Economic Analysis of Indonesia's 2015 Fire Crisis. Indonesia Sustainable Landscape Knowledge Note: 1 (World Bank Group)

Zaccone C, Rein G, D’Orazio V, Hadden RM, Belcher CM, Miano TM (2014) Smouldering fire signatures in peat and their implications for palaeoenvironmental reconstructions. Geochimica et Cosmochimica Acta. 137, 134-146. doi:10.1016/j.gca.2014.04.018 